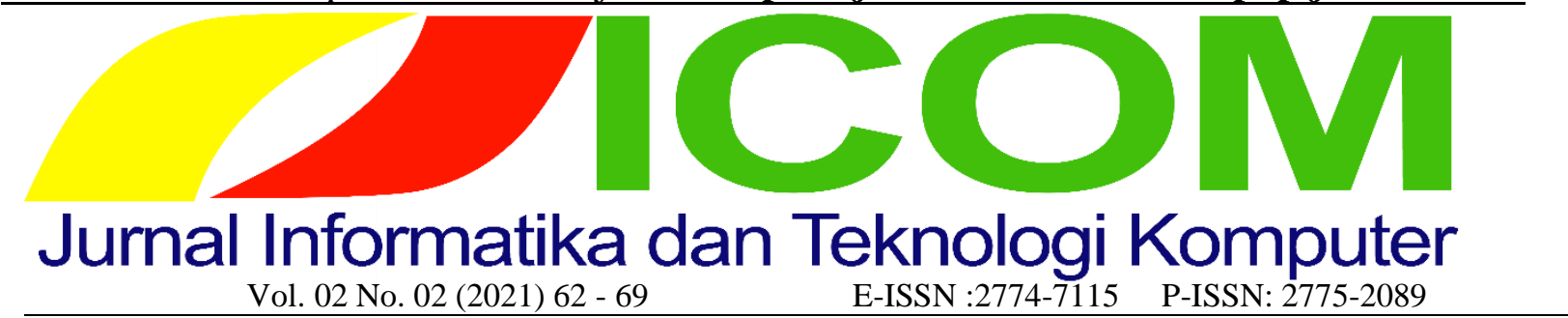

\title{
SISTEM INFORMASI PENGELOLAAN ARSIP SURAT BERBASIS WEB DI KANTOR BADAN PERTANAHAN NASIONAL KOTA LANGSA
}

\author{
Dara Havisha Lamkaruna ${ }^{1}$, Liza Fitria ${ }^{2}$ \\ Informatika, Teknik, Universitas Samudra \\ Informatika, Teknik, Universitas Samudra \\ 12darahavisha@gmail.com, ${ }^{2}$ lizafitria@unsam.ac.id
}

\begin{abstract}
The rapid development of information technology can benefit almost all fields, both government and private agencies. In an agency always needed a communication that aims to convey information without having to meet directly by means of holding a written communication called a letter. However, currently information technology is very useful to facilitate performance in correspondence activities, especially in the management of mail archives, one of which is at the Langsa City National Land Agency Office. At this time correspondence activities ranging from receiving, scheduling, archiving to verification of incoming and outgoing official letters at the Langsa City BPN Office are still using the agenda book. So with problems like this it takes quite a long time if you want to find the letter file again. From these problems, a system was created that will assist in the management of letter archives at the Langsa City Land Agency Office, namely by grouping letter archives based on letter types consisting of receipts, notifications, invitations and requests.
\end{abstract}

Keywords: Information Systems, Management, Mail

\begin{abstract}
Abstrak
Perkembangan teknologi informasi yang sangat cepat dapat dirasakan manfaatnya hampir di seluruh bidang, baik instansi pemerintah maupun swasta. Dalam suatu instansi selalu dibutuhkan suatu komunikasi yang bertujuan untuk menyampaikan suatu informasi tanpa harus bertemu langsung dengan cara diadakannya komunikasi tertulis yang disebut dengan surat. Namun saat ini teknologi informasi sangat berguna untuk mempermudah kinerja dalam kegiatan surat menyurat terutama dalam pengelolaan arsip surat yang salah satunya terdapat di Kantor Badan Pertanahan Nasional Kota Langsa. Pada saat ini aktivitas persuratan mulai dari penerimaan, pengagendaan, pengarsipan hingga verifikasi atas surat-surat dinas masuk dan keluar yang terdapat di Kantor BPN Kota Langsa masih menggunakan buku agenda. Sehingga dengan permasalahan seperti ini membutuhkan waktu yang cukup lama apabila ingin mencari berkas surat kembali. Dari permasalahan tersebut dibuat suatu sistem yang akan membantu dalam pengelolaan arsip surat di Kantor Badan Pertanahan Kota Langsa yaitu dengan pengelompokkan arsip surat berdasarkan jenis surat yang terdiri dari penerimaan, pemberitahuan, undangan dan permohonan.
\end{abstract}

Kata kunci: Sistem Informasi, Pengelolaan, Surat

\section{Pendahuluan}

Pada era globalisasi teknologi komputer memegang peranan yang sangat penting untuk membantu proses aktivitas kerja di instansi maupun diperkantoran baik dari lembaga pemerintah maupun swasta. Dalam dunia perkantoran keberadaan teknologi informasi sangat berguna untuk mempermudah kinerja dalam kegiatan sehari-hari terutama dalam pengelolaan arsip surat yang salah satunya terdapat di Kantor Badan Pertanahan Nasional Kota Langsa. 
Pada kantor BPN Kota Langsa, pengarsipan baik surat masuk maupun surat keluar ada pada sub bagian umum. Setiap surat masuk yang diterima dan surat keluar yang dikirim oleh suatu organisasi pemerintah atau swasta mempunyai nilai yang sangat penting, baik sebagai alat komunikasi, sebagai pusat ingatan, sebagai bukti otentik dan sekaligus dapat menunjukkan kegiatan hidup suatu kantor.

Namun pada saat ini aktivitas persuratan mulai dari penerimaan, pengagendaan, pengarsipan hingga verifikasi atas surat-surat dinas masuk dan keluar yang terdapat di Kantor BPN Kota Langsa masih menggunakan buku agenda. Sehingga dengan sistem pengarsipan seperti ini membutuhkan waktu yang cukup lama apabila ingin mencari berkas surat kembali. Permasalahan lain berkaitan dengan penyimpanan dalam hal ini pengarsipan hanya berupa penyimpanan berkas yang mengakibatkan kemungkinan dapat terjadinya kehilangan surat.

Kegiatan surat menyurat dalam suatu instansi harus mendapatkan perhatian yang sungguhsungguh karena isi surat instansi akan menjadi sarana pencapaian tujuan dari instansi yang bersangkutan, maka dari itu perlu adanya pengelolaan surat agar dapat menunjang operasional instansi itu sendiri. Mengingat fungsi surat yang cukup penting, perlu dibuat suatu sistem yang akan membantu dalam pengelolaan arsip surat yaitu dengan pengelompokkan arsip surat berdasarkan jenis surat yang terdiri dari penerimaan, pemberitahuan, undangan dan permohonan. Pengelolaan surat harus dilakukan setepat-tepatnya karena jika pengelolaan surat dilakukan dengan baik, maka pengarsipan surat serta kegiatan-kegiatan instansi juga akan terkelola dengan baik dan selalu dapat diikuti proses perkembangannya.

\section{Rancangan Sistem dan Analisis}

\subsection{DFD (Data Flow Diagram)}

DFD merupakan suatu diagram yang menggambarkan aliran data dari sebuah proses atau sistem untuk menyediakan informasi mengenai luaran dan masukan dari setiap entitas dan proses itu sendiri.

\subsubsection{Diagram Konteks}

DFD level 0 merupakan suatu diagram yang terdiri dari sebuah metode yang dapat menjelaskan lingkup sistem secara umum. Adapun bentuk DFD Level 0 dapat dilihat pada gambar berikut ini :

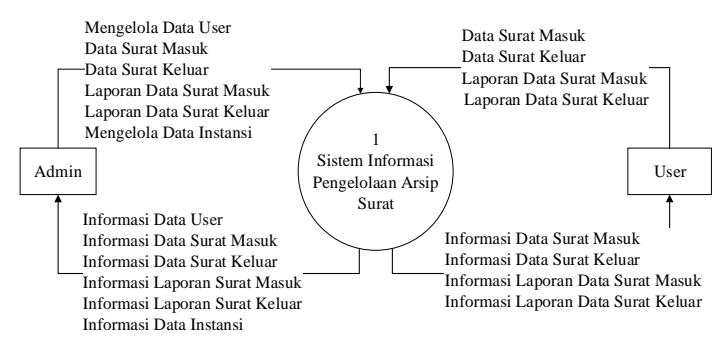

Gambar 1. Diagram Konteks

\subsubsection{DFD Level 1}

DFD level 1 bertujuan untuk memberikan pandangan mengenai keseluruhan sistem dengan lebih mendalam. Pada diagram ini terdapat 2 entitas yaitu admin dan user (petugas arsip). Dalam sistem informasi pengelolaan arsip surat ini terdapat 6 proses yang terdiri dari proses kelola data user, pengolahan data surat masuk, pengolahan data surat keluar, laporan surat masuk, laporan surat keluar dan kelola data instansi.

Dalam pengolahannya sistem dapat login sebagai admin atau user (petugas arsip). Perbedaan hak akses admin dengan user berbeda karena hanya admin yang dapat mengolah data user dan instansi.

Kemudian pada proses pengolahan data surat masuk, admin atau user (petugas arsip) melakukan input data surat masuk yang nantinya data-data yang telah dimasukkan akan disimpan pada basis data tbl_surat_masuk. Kemudian setelah melakukan input data, maka admin atau user (petugas arsip) menghasilkan ouput berupa informasi data surat masuk.

Kemudian untuk mengolah data surat keluar, data-data tersebut akan disimpan pada basis data tbl_surat_keluar. Admin dan user (petugas arsip) menghasilkan ouput berupa Informasi data surat keluar.

Laporan surat masuk dan laporan surat keluar dapat diperoleh dari data-data yang telah diinputkan pada surat masuk maupun surat keluar tersebut, hasil laporan tersebut dapat dicetak sesuai dengan tanggal,bulan dan tahun yang telah di inputkan oleh admin atau user (petugas arsip).

Dalam proses kelola data intansi, admin dapat menginputkan data intansi ke dalam sistem dan nantinya data tersebut akan disimpan pada basis data tbl_instansi. Adapun bentuk DFD Level 1 dapat dilihat pada gambar berikut : 


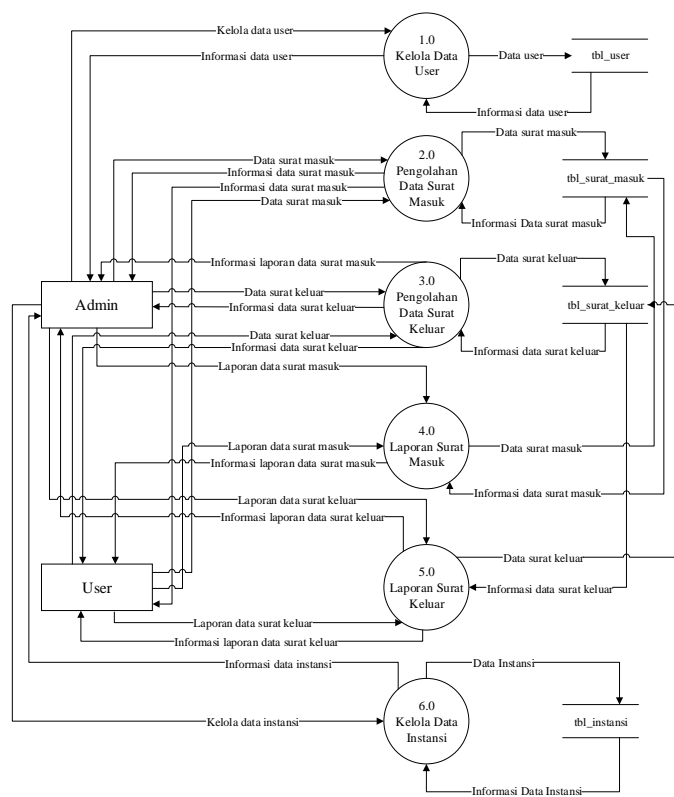

Gambar 2. Gambar DFD Level 1

\subsubsection{DFD Level 2}

DFD Level 2 terdapat 6 Proses yang bisa dilakukan pada sistem pengelolaan arsip surat.

\section{a. DFD Level 2 Proses 1}

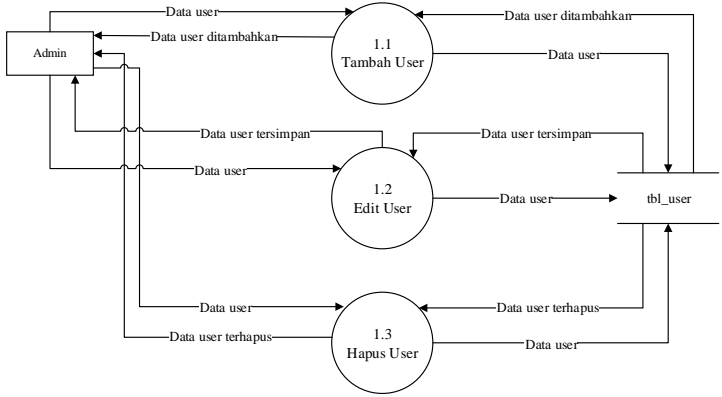

Gambar 3. DFD Level 2 Proses 1

Pada gambar 3 terdapat gambar DFD Level 2 Proses 2 tentang kelola data user, pada proses ini terdapat 3 proses yang dapat dilakukan oleh admin, yaitu tambah user yang bertujuan untuk menambahkan user baru (petugas arsip), edit user yang bertujuan untuk mengubah data user yang ada. hapus user yang bertujuan untuk menghapus data user yang telah ada.

\section{b. DFD Level 2 Proses 2}

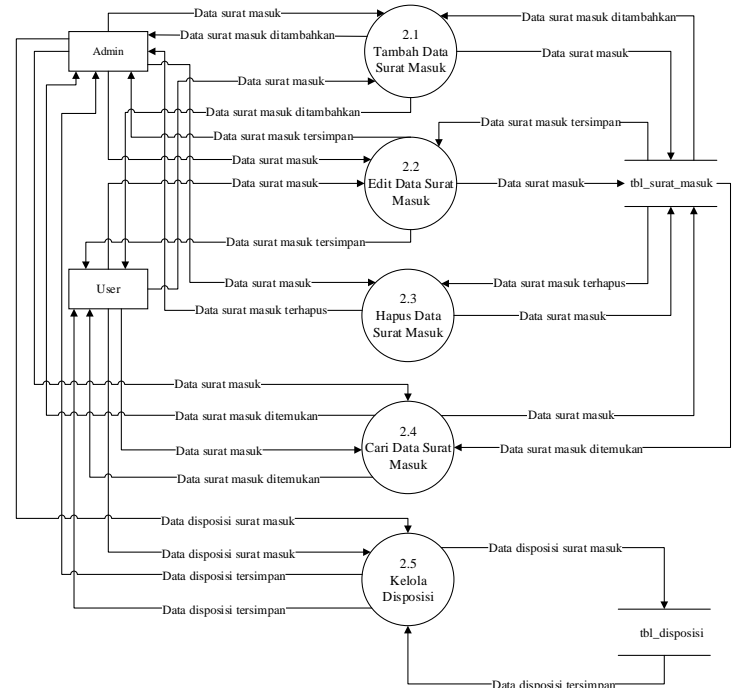

Gambar 4. DFD Level 2 Proses 2

Pada gambar 4 terdapat gambar DFD Level 2 Proses 2 tentang pengolahan data surat masuk. Pada proses ini terdapat 5 proses, yaitu tambah data surat masuk yang bertujuan untuk menambahkan data surat masuk, edit data surat masuk yang bertujuan untuk mengubah data surat masuk yang telah ada, hapus data surat masuk bertujuan untuk menghapus data surat masuk yang telah ada, cari data surat masuk bertujuan untuk mencari data surat masuk yang telah ada, kelola disposisi bertujuan untuk menindaklanjuti surat masuk sesuai dengan yang dikehendaki oleh pimpinan.

\section{c. DFD Level 2 Proses 3}

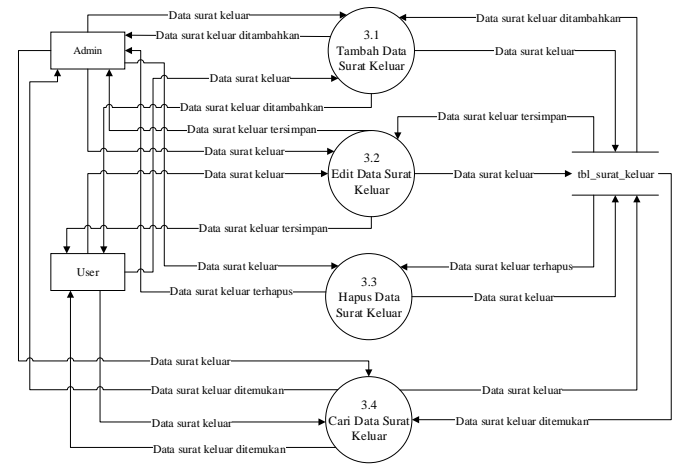

Gambar 5 DFD Level 2 Proses 3

Pada gambar 5 terdapat gambar DFD Level 2 Proses 3 yang membahas tentang pengumuman pendaftaran sertifikasi tanah pada sistem. Setelah user menginput data pendaftar, kemudian admin menyeleksi data pendaftar. Setelah diseleksi oleh admin, user dapat melihat pengumuman hasil seleksi data.

\section{d. DFD Level 2 Proses 4}




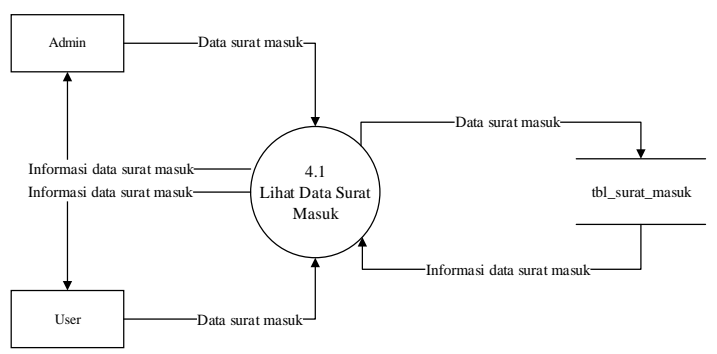

Gambar 6. DFD Level 2 Proses 4

Pada gambar 6 terdapat gambar DFD Level 2 Proses 4 tentang laporan surat masuk. Pada proses ini menggambarkan penjabaran dari proses laporan surat masuk. Setelah admin atau user (petugas arsip) menginput data surat masuk, kemudian admin atau user (petugas arsip) dapat melihat informasi data surat masuk yang telah disimpan oleh admin atau user (petugas arsip) pada basis data surat masuk.

\section{e. DFD Level 2 Proses 5}

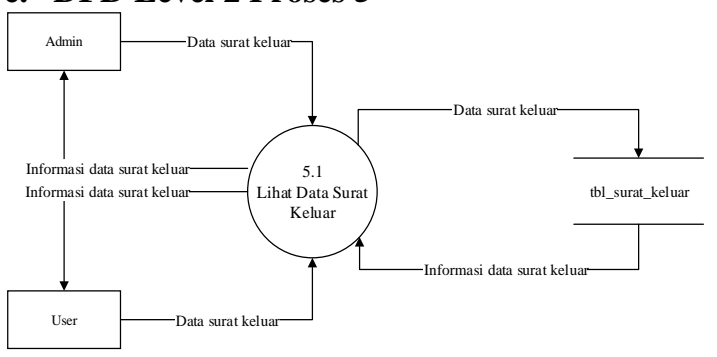

Gambar 7. DFD Level 2 Proses 5

Pada gambar 7 terdapat gambar DFD Level 2 Proses 5 tentang laporan surat keluar. Pada proses ini menggambarkan penjabaran dari proses laporan surat keluar. Setelah Admin atau user (petugas arsip) menginput data surat keluar, kemudian admin atau user (petugas arsip) dapat melihat informasi data surat keluar yang telah disimpan oleh admin atau user (petugas arsip) pada basis data surat keluar.

\section{f. DFD Level 2 Proses 6}

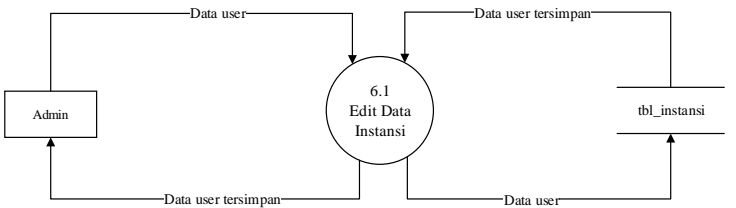

Gambar 8. DFD Level 2 Proses 6

Pada gambar 8 terdapat gambar DFD Level 2 Proses 6 tentang Kelola data instansi. Pada proses ini menggambarkan penjabaran dari proses pengolahan basis data instansi. Proses ini melibatkan seorang admin yang memiliki hak penuh atas pengelolaan data instansi. Pada proses kelola data user terdapat 3 proses yang dapat dilakukan oleh admin, yaitu edit data instansi yang bertujuan untuk mengubah data instansi yang telah ada.

\subsection{ERD (Entity Relationship Diagram)}

Entity Relationship Diagram adalah model konseptual yang mendeskripsikan hubungan antar penyimpanan (dalam DFD). Entity Relationship
Diagram menggambarkan hubungan antar entitas pada sistem informasi pengelolaan arsip surat.

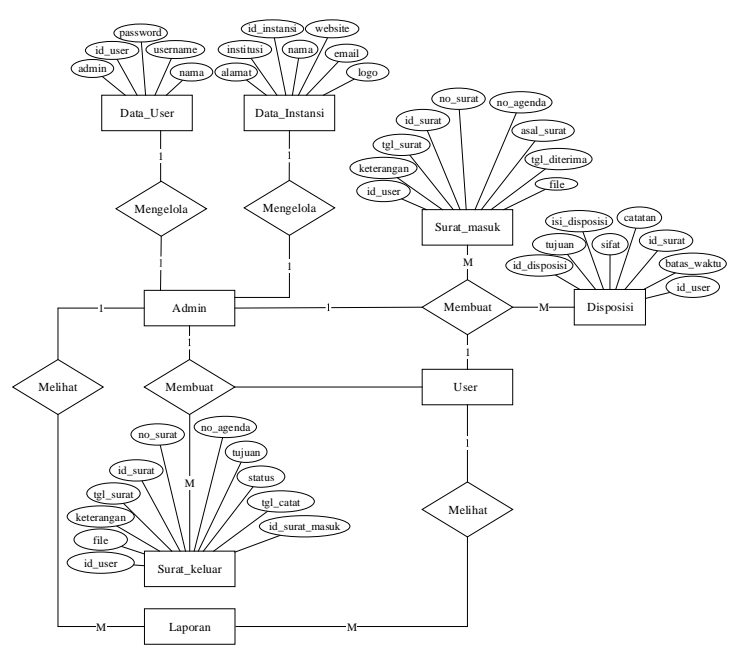

Gambar 9. Gambar ERD

\subsection{Desain Database}

Desain database adalah untuk menentukan data-data yang dibutuhkan dalam sistem, sehingga dapat mempermudah pengambilan informasi dan informasi yang dihasilkan dapat terpenuhi dengan baik.

\section{a. Desain Tabel User}

\begin{tabular}{|l|l|l|l|l|}
\hline No & $\begin{array}{l}\text { Filed } \\
\text { Name }\end{array}$ & $\begin{array}{l}\text { Data } \\
\text { Type }\end{array}$ & $\begin{array}{l}\text { Field } \\
\text { Size }\end{array}$ & Keterangan \\
\hline 1. & $\begin{array}{l}\text { id_us } \\
\text { er }\end{array}$ & INT & 10 & Id user \\
\hline 2. & $\begin{array}{l}\text { usern } \\
\text { ame }\end{array}$ & Varchar & 30 & $\begin{array}{l}\text { Nama } \\
\text { pengguna } \\
\text { akun }\end{array}$ \\
\hline 3. & $\begin{array}{l}\text { passw } \\
\text { ord }\end{array}$ & Varchar & 35 & Kata sandi \\
\hline
\end{tabular}

Tabel 1. Perancangan Tabel User

\section{b. Desain Tabel Surat Masuk}

\begin{tabular}{|l|l|l|l|l|}
\hline No & $\begin{array}{l}\text { Filed } \\
\text { Name }\end{array}$ & $\begin{array}{l}\text { Data } \\
\text { Type }\end{array}$ & $\begin{array}{l}\text { Field } \\
\text { Size }\end{array}$ & Keterangan \\
\hline 1. & id_surat & INT & 10 & Id surat \\
\hline 2. & $\begin{array}{l}\text { no_agen } \\
\text { da }\end{array}$ & INT & 10 & No agenda \\
\hline 3. & no_surat & Varch & 50 & No surat \\
\hline 4. & $\begin{array}{l}\text { asal_sura } \\
\text { t }\end{array}$ & $\begin{array}{l}\text { Varch } \\
\text { ar }\end{array}$ & 250 & Asal surat \\
\hline 5. & tgl_surat & Date & & Tanggal \\
& & & & surat \\
\hline
\end{tabular}


Dara Havisha Lamkaruna ${ }^{1}$, Liza Fitria ${ }^{2}$

Jurnal J-ICOM (Jurnal Informatika dan Teknologi Komputer) Vol. 02 No. 02 (2021) 62 - 69

\begin{tabular}{|l|l|l|l|l|}
\hline 6. & $\begin{array}{l}\text { tgl_diteri } \\
\text { ma }\end{array}$ & Date & & $\begin{array}{l}\text { Tanggal } \\
\text { diterima }\end{array}$ \\
\hline 7. & file & $\begin{array}{l}\text { Varch } \\
\text { ar }\end{array}$ & 250 & File surat \\
\hline 8. & $\begin{array}{l}\text { keterang } \\
\text { an }\end{array}$ & $\begin{array}{l}\text { Varch } \\
\text { ar }\end{array}$ & 250 & keterangan \\
\hline 9. & id_user & INT & 10 & Id user \\
\hline
\end{tabular}

Tabel 2. Perancangan Tabel Surat Masuk

\section{c. Desain Tabel Surat Keluar}

\begin{tabular}{|c|c|c|c|c|}
\hline No & $\begin{array}{l}\text { Filed } \\
\text { Name }\end{array}$ & $\begin{array}{l}\text { Data } \\
\text { Type }\end{array}$ & $\begin{array}{l}\text { Fiel } \\
\mathrm{d} \\
\text { Size }\end{array}$ & Keterangan \\
\hline 1. & id_surat & INT & 10 & Id surat \\
\hline 2. & $\begin{array}{l}\text { no_agend } \\
\text { a }\end{array}$ & INT & 10 & No agenda \\
\hline 3. & no_surat & $\begin{array}{l}\text { Varcha } \\
\text { r }\end{array}$ & 50 & No surat \\
\hline 4. & tujuan & $\begin{array}{l}\text { Varcha } \\
\text { r }\end{array}$ & 250 & $\begin{array}{l}\text { Tujuan } \\
\text { surat }\end{array}$ \\
\hline 5. & tgl_surat & Date & & $\begin{array}{l}\text { Tanggal } \\
\text { surat }\end{array}$ \\
\hline 6. & tgl_catat & Date & & $\begin{array}{l}\text { Tanggal } \\
\text { catat }\end{array}$ \\
\hline 7. & file & $\begin{array}{l}\text { Varcha } \\
\text { r }\end{array}$ & 250 & File surat \\
\hline 8. & $\begin{array}{l}\text { keteranga } \\
\mathrm{n}\end{array}$ & $\begin{array}{l}\text { Varcha } \\
\mathrm{r}\end{array}$ & 250 & keterangan \\
\hline 9. & status & $\begin{array}{l}\text { Varcha } \\
r\end{array}$ & 1 & Id user \\
\hline 10. & $\begin{array}{l}\text { Id_surat_ } \\
\text { masuk }\end{array}$ & $\begin{array}{l}\text { Varcha } \\
\mathrm{r}\end{array}$ & 10 & $\begin{array}{l}\text { Id surat } \\
\text { masuk }\end{array}$ \\
\hline 11. & Id_user & INT & 10 & Id user \\
\hline
\end{tabular}

Tabel 3. Desain Tabel Surat Keluar

\section{d. Desain Tabel Disposisi}

\begin{tabular}{|l|l|l|l|l|}
\hline No & $\begin{array}{l}\text { Filed } \\
\text { Name }\end{array}$ & $\begin{array}{l}\text { Data } \\
\text { Type }\end{array}$ & $\begin{array}{l}\text { Field } \\
\text { Size }\end{array}$ & Keterangan \\
\hline 1. & $\begin{array}{l}\text { id_dispos } \\
\text { isi }\end{array}$ & INT & 10 & Id disposisi \\
\hline 2. & tujuan & INT & 10 & $\begin{array}{l}\text { Tujuan } \\
\text { disposisi }\end{array}$ \\
\hline 3. & $\begin{array}{l}\text { isi_dispos } \\
\text { isi }\end{array}$ & $\begin{array}{l}\text { Varc } \\
\text { har }\end{array}$ & 50 & Isi disposisi \\
\hline 4. & sifat & $\begin{array}{l}\text { Varc } \\
\text { har }\end{array}$ & 100 & $\begin{array}{l}\text { Sifat } \\
\text { disposisi }\end{array}$ \\
\hline
\end{tabular}

\begin{tabular}{|l|l|l|l|l|}
\hline 5. & $\begin{array}{l}\text { batas_wa } \\
\text { ktu }\end{array}$ & Date & & Batas waktu \\
\hline 6. & catatan & $\begin{array}{l}\text { Varc } \\
\text { har }\end{array}$ & 250 & $\begin{array}{l}\text { Catatan } \\
\text { disposisi }\end{array}$ \\
\hline 7. & id_surat & INT & 10 & Id surat \\
\hline 8. & id_user & INT & 10 & Id user \\
\hline
\end{tabular}

Tabel 4. Perancangan Tabel Disposisi

\section{e. Desain Tabel Instansi}

\begin{tabular}{|l|l|l|l|l|}
\hline No & $\begin{array}{l}\text { Filed } \\
\text { Name }\end{array}$ & $\begin{array}{l}\text { Data } \\
\text { Type }\end{array}$ & $\begin{array}{l}\text { Field } \\
\text { Size }\end{array}$ & Keterangan \\
\hline 1. & id_instansi & INT & 10 & Id instansi \\
\hline 2. & institusi & Varchar & 150 & $\begin{array}{l}\text { Nama } \\
\text { instansi }\end{array}$ \\
\hline 3. & nama & Varchar & 150 & $\begin{array}{l}\text { Nama } \\
\text { daerah } \\
\text { instansi }\end{array}$ \\
\hline 4. & website & Varchar & 50 & $\begin{array}{l}\text { Nama } \\
\text { website }\end{array}$ \\
\hline 5. & email & Varchar & 50 & $\begin{array}{l}\text { Email } \\
\text { instansi }\end{array}$ \\
\hline 6. & logo & Varchar & 250 & $\begin{array}{l}\text { Logo } \\
\text { instansi }\end{array}$ \\
\hline 7. & id_user & INT & 10 & Id user \\
\hline
\end{tabular}

\section{Hasil dan Pembahasan}

\subsection{Halaman Utama}

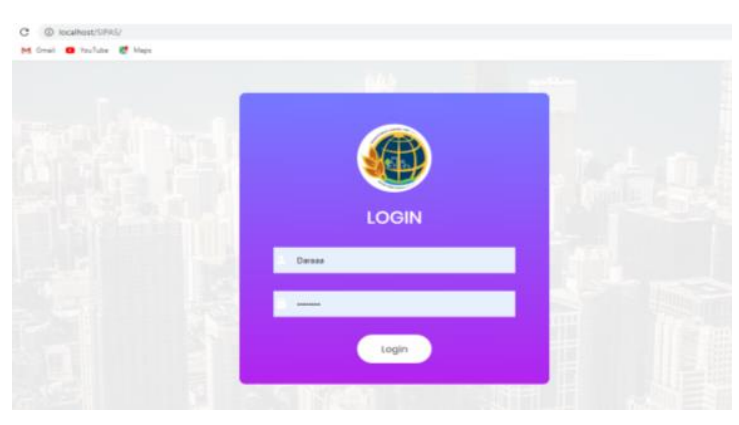

Gambar 10. Halaman Utama

Pada gambar 10 terdapat tampilan halaman utama sebelum user melakukan proses arsip surat. Sistem akan menampilkan halaman login. Admin atau user (petugas arsip) dapat login dengan memasukkan username dan password. 


\subsection{Halaman Dashboard}

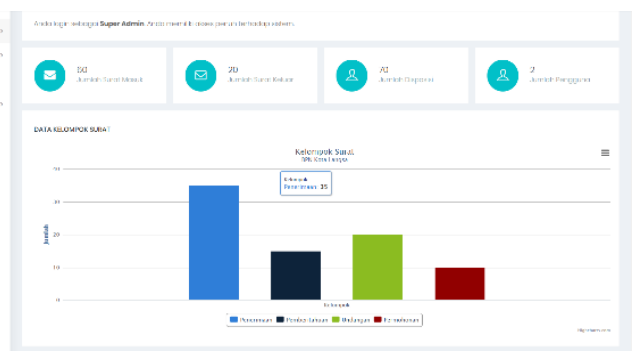

Gambar 11. Halaman Dashboard

Pada gambar 11 terdapat halaman dashboard. Halaman dashboard bertujuan untuk menampilkan informasi yang mudah dibaca. Pada halaman dashboard terdapat informasi jumlah surat masuk, jumlah surat keluar, jumlah disposisi, jumlah pengguna sistem tersebut dan juga terdapat informasi kelompok surat berdasarkan jenis surat yang terdiri dari penerimaan, pemberitahuan, undangan dan permohonan.

\subsection{Halaman Tambah Surat Masuk}

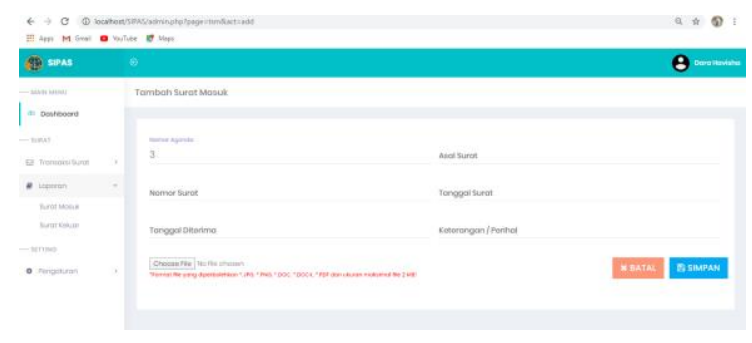

Gambar 12 Halaman Tambah Surat Masuk

Pada gambar 12 terdapat halaman tambah surat masuk. Pada halaman ini admin atau user (petugas arsip) dapat menambah arsip surat masuk dengan mengisi data surat masuk pada form di halaman tambah surat masuk. Form tersebut wajib diisi sebelum arsip surat masuk disimpan.

\subsection{Halaman Edit Surat Masuk}

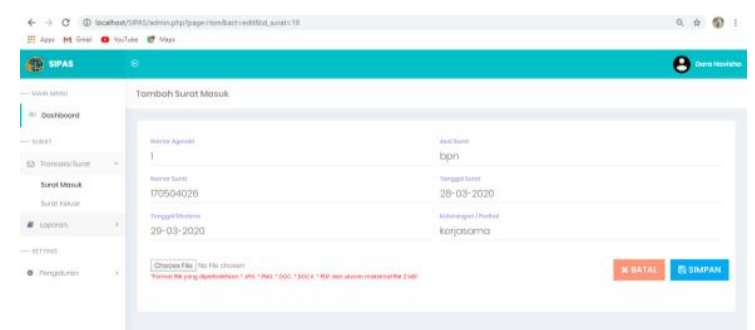

Gambar 13. Halaman Edit Surat Masuk

Pada gambar 13 terdapat halaman edit surat masuk. Pada halaman ini admin atau user (petugas arsip) dapat mengubah data surat masuk yang telah disimpan dengan mengisi data surat masuk pada form di halaman edit surat masuk.

\subsection{Halaman Tambah Disposisi}

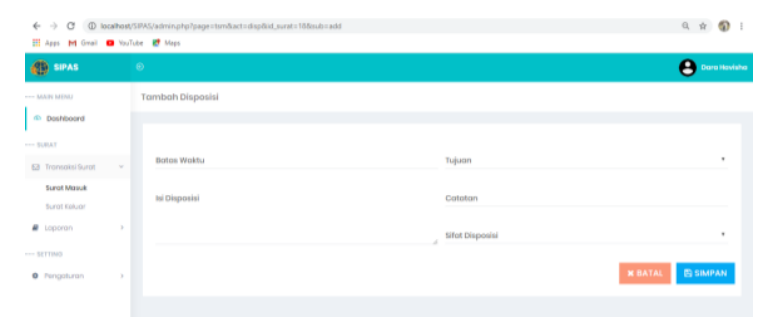

Gambar 14. Halaman Tambah Disposisi

Pada gambar 14 terdapat halaman tambah disposisi surat masuk untuk memberikan catatan pada disposisi surat masuk. Biasanya disposisi dapat berupa tanggapan, saran atau instruksi. Disposisi pada sistem ini terdapat tujuan untuk petunjuk mengenai tindak lanjut dari penyelesaian surat.

\subsection{Halaman Edit Disposisi}

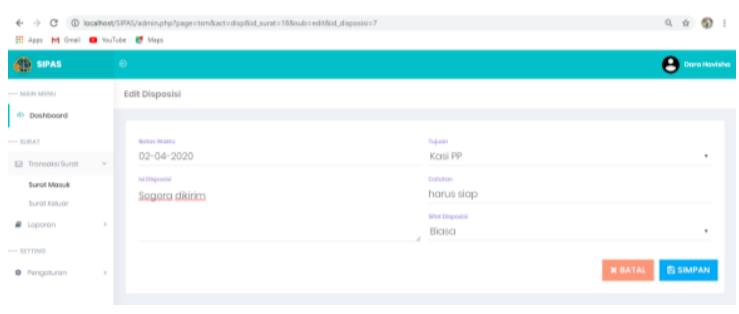

Gambar 15. Halaman Edit Diposisi

Pada gambar 15 terdapat halaman edit disposisi. Pada halaman ini admin atau user (petugas arsip) dapat mengubah data disposisi surat masuk yang telah disimpan dengan mengisi data disposisi pada form di halaman edit disposisi.

\subsection{Halaman Tambah Surat Keluar}

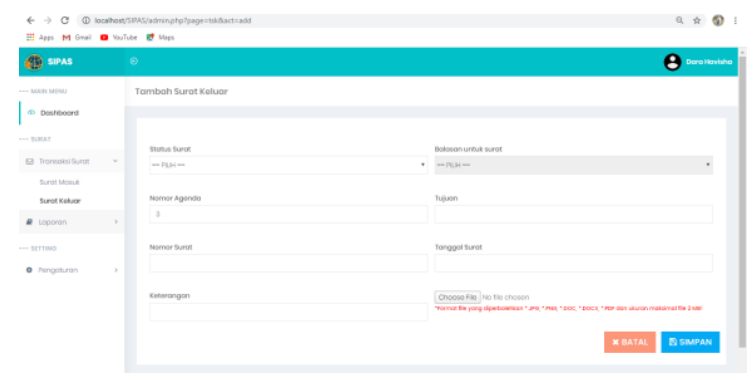

Gambar 16. Tambah Surat Keluar

Pada gambar 16 terdapat halaman tambah surat keluar. Pada halaman ini admin atau user (petugas arsip) dapat menambah arsip surat keluar dengan mengisi data surat keluar pada form di halaman tambah surat keluar. Pada halaman tambah surat keluar terdapat pilihan status surat yang terdiri dari status surat baru atau surat balasan untuk surat masuk yang saling berhubungan. Form tersebut wajib diisi sebelum arsip surat keluar disimpan. 


\subsection{Halaman Edit Surat Keluar}

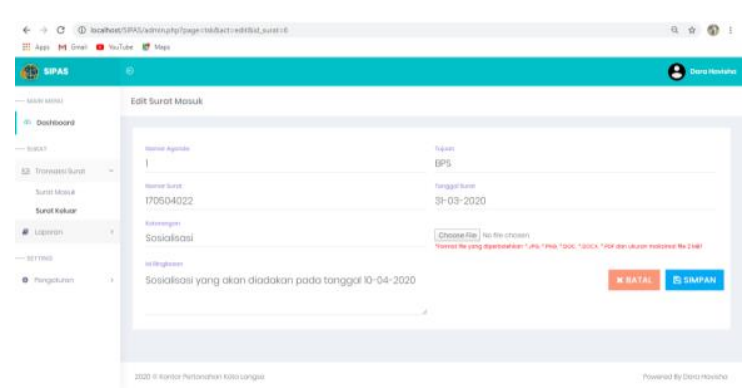

Gambar 17. Edit Surat Keluar

Pada gambar 17 terdapat halaman edit surat keluar. Pada halaman ini admin atau user (petugas arsip) dapat mengubah data surat keluar yang telah disimpan dengan mengisi data surat keluar pada form di halaman edit surat keluar.

\subsection{Halaman Laporan Surat Masuk}

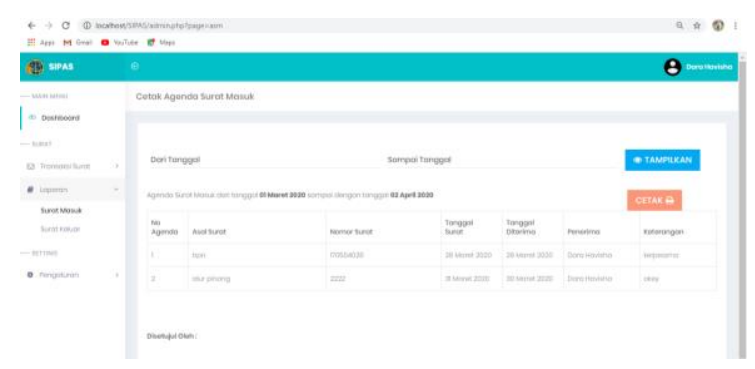

Gambar 18. Halaman Laporan Surat Masuk

Pada gambar 18 terdapat halaman laporan surat masuk. Pada sistem ini, laporan surat masuk bertujuan untuk memberikan informasi data surat masuk yang telah disimpan sesuai dengan tanggal yang ditentukan dan juga laporan tersebut dapat dicetak dengan klik menu "cetak".

\subsection{Halaman Laporan Surat Keluar}

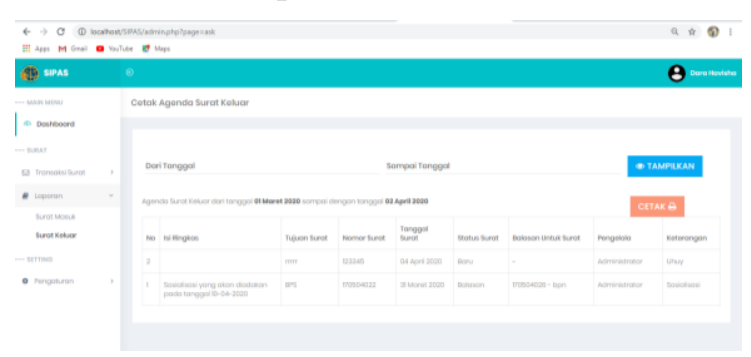

Gambar 19. Halaman Laporan Surat Keluar

Pada gambar 19 terdapat halaman laporan surat keluar. Pada sistem ini, laporan surat keluar bertujuan untuk memberikan informasi data surat keluar yang telah disimpan sesuai dengan tanggal yang ditentukan dan juga laporan tersebut dapat dicetak dengan klik menu "cetak".

\subsection{Halaman Tambah User}

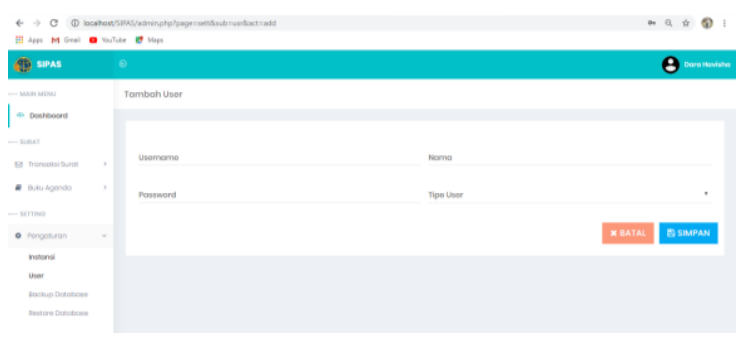

Gambar 20. Halaman Tambah User

Pada gambar 20 terdapat halaman tambah user. Halaman tambah user hanya dapat dikelola oleh admin. Pada halaman ini admin dapat menambah user (petugas arsip) dengan mengisi username, password, nama dan tipe user di halaman tambah user. Setelah data terisi dengan lengkap maka data dapat disimpan. Data tersebut tersimpan di halaman manajemen user.

\subsection{Halaman Edit user}

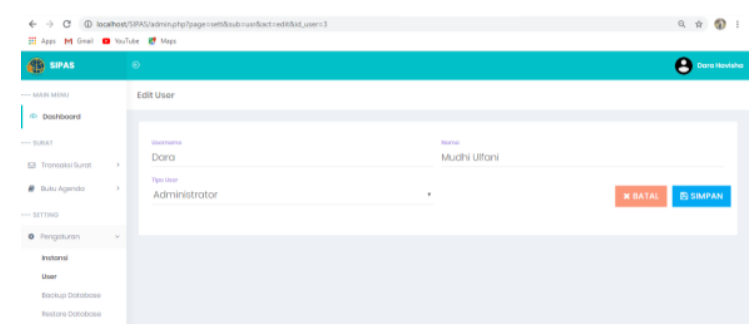

Gambar 21. Halaman Edit User

Pada gambar 21 terdapat halaman edit user (petugas arsip). Halaman edit user hanya dapat dikelola oleh admin. Pada halaman ini admin dapat mengubah data user yang telah disimpan dengan mengisi data user pada form di halaman edit user.

\subsection{Halaman Edit Data Instansi}

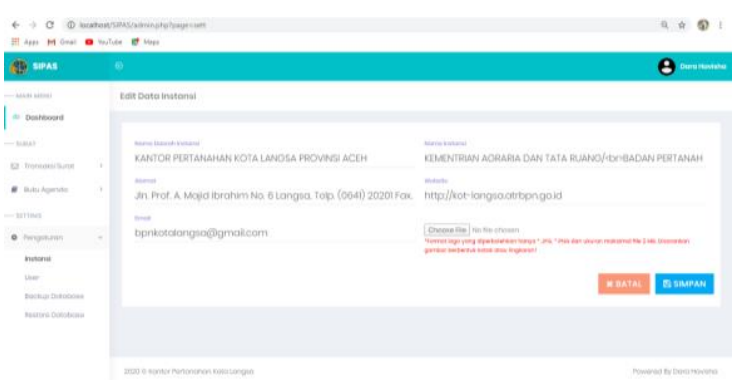

Gambar 22. Halaman Edit Data Instansi

Pada gambar 22 terdapat halaman edit data instansi. Halaman edit data instansi hanya dapat dikelola oleh admin. Pada halaman ini admin dapat mengubah data instansi yang telah disimpan dengan mengisi data instansi pada form di halaman edit data instansi 


\subsection{Halaman Backup Database}

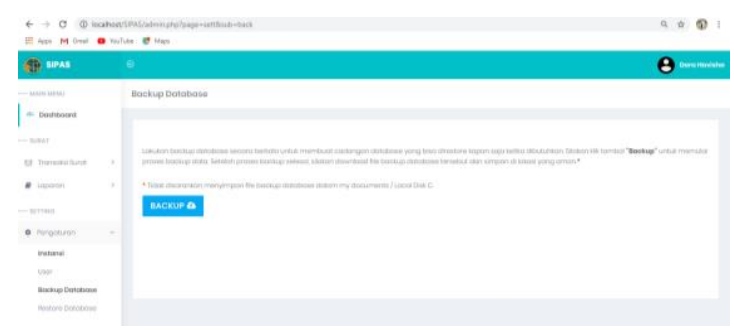

Gambar 23. Halaman Backup Database

Pada gambar 23 terdapat halaman backup database. Backup database bertujuan untuk mengembalikan data apabila kehilangan data master. Backup database juga berguna untuk mengembalikan data ke titik waktu tertentu. Untuk melakukan backup database pada sistem ini, silahkan klik tombol "Backup" untuk memulai proses backup data. Setelah proses backup selesai, silahkan download file backup database tersebut dan simpan di lokasi yang aman.

\subsection{Halaman Restore Database}

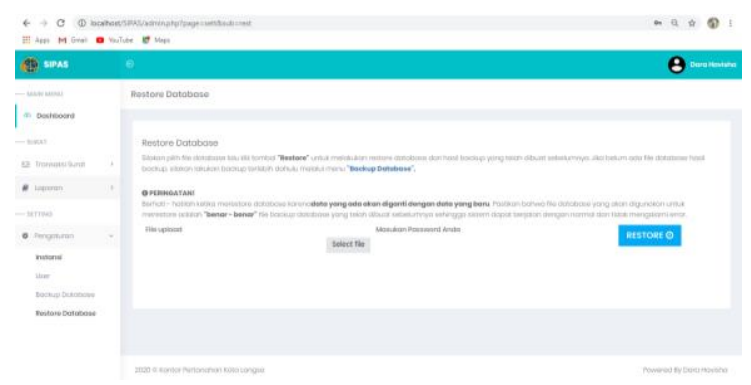

Gambar 24. Halaman Restore Database

Pada gambar 24 terdapat halaman restore database. Restore database adalah proses pengambilan kembali database yang dibackup. Proses restore ini dijalankan jika database yang sedang digunakan mengalami kerusakan sehingga tidak dapat digunakan. Pada halaman restore database ini, silahkan masukkan password terlebih dahulu sebelum melakukan restore database, kemudian pilih file database dan klik tombol "Restore" untuk melakukan restore database dari hasil backup yang telah dibuat sebelumnya.

\section{Kesimpulan}

Adapun kesimpulan dari sistem informasi pengelolaan arsip surat ini yaitu sebagai berikut:

1. Sistem informasi pengelolaan arsip surat ini digunakan untuk mengelola pengarsipan surat di kantor BPN Langsa berdasarkan jenis suratnya. Jika dibutuhkan, surat yang telah diarsipkan dapat dilihat data-data serta file digital dari surat tersebut yang merupakan hasil scan dari surat aslinya oleh pengguna sistem.

2. Terdapat 4 kelompok jenis surat di BPN Langsa yaitu terdiri dari surat penerimaan, pemberitahuan, undangan dan permohonan. Data dari tanggal 1 maret sampai 27 Mei menunjukkan bahwa jenis surat penerimaan berjumlah 35 surat, surat pemberitahuan berjumlah 15 surat, surat

\section{Daftar Pustaka}

[1] Afyenni, Rita, 2014. Perancangan Data Flow Diagram Untuk Sistem Informasi Sekolah (Studi Kasus Pada Sma Pembangunan Laboratorium UNP). Jurnal TEKNOIF. 2(1): 35-39

[2] Al Fatta, Hanif. 2017. Analisis \& Perancangan Sistem Informasi. Yogyakarta: Andi.

[3] Arief, Rudyanto. 2011. Pemrograman Web Dinamis Menggunakan PHP \& MySQL. Yogyakarta: Andi.

[4] Fathansyah. 2002. Basis Data. Jakarta : Elex Media Komputindo.

[5] Jogiyanto. 2014. Sistem Teknologi Informasi. Yogyakarta: Andi.

[6] Kristanto, Andri. 2018. Perancangan Sistem Informasi dan Aplikasinya. Yogyakarta: Gava Media.

[7] Oetomo, Budi Sutedjo Dharma. 2006. Perencanaan dan Pembangunan Sistem Informasi. Yogyakarta: Andi.

[8] Rogers Pressman, Ph. D, 1997. Pengembangan Sistem Informasi. Jakarta : Salemba Infotek.

[9] Pohan, H. Iskandar dan K. Saiful Bahri. 1997. Pengantar Perancangan Sistem. Jakarta: Erlangga.

[10] Ruang Lingkup BPNRI Tahun 2014 Tentang Sejarah Singkat Badan Pertanahan Nasional (BPN).

[11] Santoso, Leo Williyanto, 2013. Pelatihan Microsoft Visio 2010 Profesional. Pusat Komputer Universitas Kristen Petra.

[12] Sutabri, Tata. 2015. Sistem Informasi Manajemen. Yogyakarta: Andi. 